\title{
Senior High School Students' Attitudes Through Inquiry-Based Learning
}

\author{
M. Zaini, Amalia Rezeki \\ Universitas Lambung Mangkurat \\ Banjarmasin, South Kalimantan \\ muhammadzaini@ulm.ac.id, amaliarezeki@ulm.ac.id
}

\author{
Fathul Zannah \\ Universitas Muhammadiyah Palangkaraya \\ Palangkaraya, Central Kalimantan \\ pesona.bio06@gmail.com
}

\begin{abstract}
This is a descriptive study aimed to identify students' attitudes during the learning process through inquiry based learning. The attitudes cover character behavior and social skills observed during the learning process. The indicators of character behavior are cooperation and appreciation to friends, while the indicator of social skill is questioning. The research subjects were the eleventh graders of IPA 1 SMA Negeri 2 Banjarbaru. The focus of this study is five students with different academic abilities. The data analysis was in the form of descriptive data and categorized with scales: very good (A), good (B), sufficient (C), and low (D).The result shows that the students' attitudes during the learning process are in good category viewed from the character behavior parameter (cooperation and appreciation to friends). The social skill of the students is also in good category viewed from the questioning indicator.
\end{abstract}

Keywords-character behavior; social skill; inquiry-based learning; students

\section{INTRODUCTION}

National education develops the ability, forms mindset, and dignified national civilization to create bright and educated citizens. National education also develops students' potentials to create human beings who believe in and obey the God, show noble attitudes, stay healthy, educated, skillful, creative, independent, democratic, and responsible [1]. Education then is a way to prepare human beings for a bright and quality future to make them able to face the challenges of the new era.

One of the assessment aspects of students learning outcome in high schools is the attitude aspect [2]. This assessment will portray the students' tangible attitude during the learning process. This attitude aspect is taught to them since the beginning to equip them to be part of a bigger society in the future.

The assessment process so far has been emphasizing on one aspect of knowledge only while ignoring skill and attitude aspects. The learning assessment basically is to cover three aspects: knowledge, skill, and attitude [3]. If it is done, the assessment towards the learning achievement will be complete and thorough. One of the ways to do that is through inquiry based learning.

Inquiry based learning demands students to obtain both the learning result and process which cover knowledge, psychomotor, and attitude [4]. Human regulation system concept is set to facilitate students to do observation. When learning a concept, students can observe, formulate problems, formulate a hypothesis, gather data, test the hypothesis, and make conclusions related to the nerve system, endocrine system, and sense system on a human being. They are trained to work together, to be tolerant of friends in one group, to be thorough, and to be persistent. The students' needs today is learning process change from being told to finding out and from output based assessment to output and process based assessment.

Ref [5] explained his observation on attitude indicators to obtain student assessment result. The attitude in learning is a learning outcome which focuses on their feeling. It is the basis of attitude and habit of the students in the future. Therefore, it is necessary to observe character attitude and social skill.

Attitude aspect can be trained to the students during the learning process. Inquiry based learning model and cooperative learning model can be used to explore students' attitude. The inquiry based learning process demands the students to be thorough, persistent, and responsible. Meanwhile, the cooperative learning model demands the students to be tolerant and cooperative. Therefore, when these two models are used together in the learning process, it provides chances to students to understand a learning concept and work together by sharing ideas among group members and at the same time keep being thorough, persistent, and responsible.

The inquiry based learning model is combined with the cooperative model aiming to make the learning meaningful [6]. One of the meaningful learning criteria is a chance to ask [7]. When a student asks in the inquiry process during the learning, he or she plays an active role in developing an understanding which produces meaningful learning.

The learning outcome is the representation of abilities expected to be possessed by the students after completing their learning process [8]. The learning outcome is connected with the learning process. What happens during the learning process determines what information the students obtain and process in themselves. How the information becomes a learning outcome which is relevant with the learning goal is influenced by the internal condition of the student and the environment. When an attitude is assumed to be accommodated in the learning process, it will contribute well 
to the learning achievement. In other words, character behavior and social skill can be developed through inquiry based learning.

\section{METHOD}

Observation (descriptive research) is conducted four times to complete the concept of the human regulation system. The research subjects were the eleventh graders of IPA 1 SMA Negeri 2 Banjarbaru. The focus of the research (number of subject in this study) was five students with different academic abilities.

This study used the learning in the inquiry-based setting with a combination of cooperative learning models at the time of application in the classroom. Cooperative learning facilitates students working in groups. Furthermore, the observation of student attitudes that emerged during work in the group was done by three observers.

The indicators of character behavior are cooperation and appreciation to friends while the indicator of social skill is questioning. The data was gathered through observation using instruments of character behavior and social skill. The data were analyzed descriptively and categorized with the scales of very good (A), good (B), sufficient (C), and low (D).

The character behavior of cooperation aspect was observed with five parameters: very good (5), good (4), sufficient (3), and low (1-2). The character behavior of appreciative to friends aspect could be observed using six parameters namely: very good (6), good (4-5), sufficient (3), and low (1-2). Then, the social skill of questioning was observed using four parameters: very good (4), good (3), sufficient (2), and low (1). The observers observe students by giving a check mark on the rubric based on the attitude that appears during the learning took place. The categories of very good, good, sufficient and less were determined by the quantity of appearance of the attitude shown by the students.

\section{RESULTS AND DISCUSSION}

\section{A. Students' Character Behavior}

Observation result on the students' character behavior is displayed in Table I. Table 1 shows that the cooperation of the students in learning is good. The observation result of students character behavior (appreciate friends) is displayed in Table II.

TABLE I. OBSERVATION RESUlt ON THE STUDENT COOPERATION BEHAVIOR

\begin{tabular}{|c|c|c|c|c|c|c|c|c|c|}
\hline \multirow{3}{*}{ Category } & \multicolumn{8}{|c|}{ Cooperation } & \multirow{3}{*}{$\begin{array}{c}\text { Average } \\
(\%)\end{array}$} \\
\hline & \multicolumn{2}{|c|}{ Meeting 1} & \multicolumn{2}{|c|}{ Meeting 2} & \multicolumn{2}{|c|}{ Meeting 3} & \multicolumn{2}{|c|}{ Meeting 4} & \\
\hline & $\sum$ & $\%$ & $\sum$ & $\%$ & $\sum$ & $\%$ & $\sum$ & $\%$ & \\
\hline $\mathrm{A}$ & 0 & 0 & 2 & 40 & 3 & 60 & 3 & 60 & 40 \\
\hline $\mathrm{B}$ & 4 & 80 & 3 & 60 & 2 & 40 & 2 & 40 & 55 \\
\hline $\mathrm{C}$ & 1 & 20 & 0 & 0 & 0 & 0 & 0 & 0 & 5 \\
\hline $\mathrm{D}$ & 0 & 0 & 0 & 0 & 0 & 0 & 0 & 0 & 0 \\
\hline
\end{tabular}

TABLE II. OBSERVATION RESULT OF APPRECIATIVE TO FRIENDS BEHAVIOR

\begin{tabular}{|c|c|c|c|c|c|c|c|c|c|}
\hline \multirow{3}{*}{ Category } & \multicolumn{8}{|c|}{ Appreciative to friends } & \multirow{3}{*}{$\begin{array}{c}\text { Average } \\
(\%)\end{array}$} \\
\hline & \multicolumn{2}{|c|}{ Meeting 1} & \multicolumn{2}{|c|}{ Meeting 2} & \multicolumn{2}{|c|}{ Meeting 3} & \multicolumn{2}{|c|}{ Meeting 4} & \\
\hline & $\sum$ & $\%$ & $\sum$ & $\%$ & $\sum$ & $\%$ & $\sum$ & $\%$ & \\
\hline $\mathrm{A}$ & 0 & 0 & 2 & 40 & 4 & 80 & 4 & 80 & 50 \\
\hline $\mathrm{B}$ & 5 & 100 & 3 & 60 & 1 & 20 & 1 & 20 & 50 \\
\hline $\mathrm{C}$ & 0 & 0 & 0 & 0 & 0 & 0 & 0 & 0 & 0 \\
\hline $\mathrm{D}$ & 0 & 0 & 0 & 0 & 0 & 0 & 0 & 0 & 0 \\
\hline
\end{tabular}

Table II shows that appreciating friends among the eleventh graders of IPA 1 has been done nicely. Ref [9] mentions that character building is an important part of the learning process. Character behavior showed by the students is the result of exercise/ habituation through inquiry based learning. The steps to find concept understanding in the inquiry process demands the students to work together to achieve the shared goals.

Ref [10] argues that cooperative learning is a fundamental part of growing and developing students' moral and character. The assignments given to the students during the learning stimulate curiosity [11]. The combination of both leads to the students' activeness in exploring and finding out the answer to their curiosity. When they work together to achieve certain goals in accomplishing the group task, they have to have the appreciative character to make the cooperation goes well among peers. In other words, cooperation (working together) and appreciativeness can be accommodated and facilitated through inquiry based learning led through cooperative setting. The character is what determines human quality [12]. Therefore, character behavior is supposed to be implemented in human life such as during school life. The learning process is happening at school is supposed to grow the students' awareness and habituate character education in themselves.

The observation on the students' character behavior which has been done four times has shown that generally, character behaviors of the students are in good category; some students' character behaviors are in very good category, and sufficient category only showed up in one person and one meeting only. It indicates that the character behavior which is viewed from cooperation and appreciativeness aspects have been integrated into their selves through the learning process. It can be inferred that there is some relation between character behavior of the students and the learning process applied in the classroom.

The notion that students' behavior becomes better after the learning program through inquiry [13] has gone along with this research result. It is indicated by the findings showing the character behaviors of the students viewed from cooperation and appreciativeness indicators in four time meetings. The percentage of character behaviors of the students in cooperation aspects shows that $80 \%$ is in good category and $20 \%$ is in sufficient category (meeting 1 ), $40 \%$ is in very good category and $60 \%$ is in good category (meeting 2), $60 \%$ is in very good category is $40 \%$ are in good category (meeting 3 and 4). Meanwhile, in appreciativeness aspect, it is found out that $100 \%$ is in good category (meeting 1), $40 \%$ is in very good category, and $60 \%$ is in good category (meeting 2), $80 \%$ is in very good category and $20 \%$ is in good category 
(meeting 3 and 4). Appreciativeness also has a positive correlation with cooperation, which is shown by the students in their group performance.

Inquiry based learning directs the students to build understanding during their group works [14]. The students are grouped heterogeneously consisting of students with different abilities, sexes, and ethnics. Such a group is meant to learn together as a team to achieve a shared goal. Inquiry based learning which is designed to be cooperative can facilitate students to learn in a group and try to make a discovery (as a shared goal) which is part of their inquiry tasks.

Inquiry based learning can be combined with cooperative learning [15]. Character behavior of the students can be stimulated through the learning which is designed to make students work together in a group and cooperate to achieve shared goals. In the process to achieve the goals, the students are demanded to be able to appreciate each other so that their purpose can be achieved by collecting and accommodating different ideas and notions from each group member. This statement is relevant with what was stated by reference [16] that students' interaction among themselves can be developed when they work on inquiry tasks in the inquiry based learning. Therefore, the inquiry based model is considered relevant in training the students to have character behavior.

Willingness to cooperate with other people emerges in the students during the inquiry based learning process; this is supported by reference [17] who states that when the students learn with inquiry based cooperative learning strategy, they will start identifying the abilities of each group member, cooperating in small groups, and showing combined group members' abilities. The researchers found that their appreciative attitude towards one another influences identification done by the group towards its members and the cooperation among them which form group performance. The inquiry based cooperative learning then does not only result in cooperative attitude but also appreciative attitude.

Ref [18] finds that most of the students from the two groups (2011 and 2012) achieved good scores in the inquiry based learning. The records on their characteristics also point out that they mostly have good attitude. Their cooperation within four-time observation also shows good category with the average score of $55 \%$, followed by very good category with average score of $40 \%$; and only $5 \%$ categorized as sufficient. The students' appreciation of their friends' opinions is also in good and very good categories, with an average score of $50 \%$ for each of both categories.

The inquiry based learning process demands the students to pay their attentions in the class discussion and participate actively in group work [19]. In a group, the students are assigned with a task that would lead to the participation of each group member. The students need to be trained to appreciate their friends to achieve success since during the cooperation process there might be differences in opinions among them. The research result shows that the inquiry based learning model which is arranged cooperatively inures them to show appreciation to their friends which is in good to very good category.
The inquiry based learning is related to the students' tendency to positive attitude [20]. Cooperative and appreciative attitude development found on the eleventh graders of IPA 1 SMAN 2 Banjarbaru. The students are demanded to show their maximum potential in the inquiry based learning to train the students to be more cooperative among them to optimally achieve their goals. The finding of the study shows an increase from fair category to good category and in the end moves to very good category (in the fourth/last meeting) which indicates that there is a development in the students' character behavior from one meeting to another.

\section{B. Social Skill}

Students' social skill in one group, as the researcher observed, is done to group three. The observation result on social skill in questioning aspect during the learning process is displayed in Table 3.

TABLE III. OBSERVATION RESULT OF QUESTIONING SKILL

\begin{tabular}{|c|c|c|c|c|c|c|c|c|c|}
\hline \multirow{3}{*}{ Category } & \multicolumn{8}{|c|}{ Questioning } & \multirow{3}{*}{$\begin{array}{c}\text { Average } \\
(\%)\end{array}$} \\
\hline & \multicolumn{2}{|c|}{ Meeting 1} & \multicolumn{2}{|c|}{ Meeting 2} & \multicolumn{2}{|c|}{ Meeting 3} & \multicolumn{2}{|c|}{ Meeting 4} & \\
\hline & $\sum$ & $\%$ & $\sum$ & $\%$ & $\sum$ & $\%$ & $\sum$ & $\%$ & \\
\hline $\mathrm{A}$ & 0 & 0 & 2 & 40 & 3 & 60 & 3 & 60 & 40 \\
\hline $\mathrm{B}$ & 3 & 60 & 3 & 60 & 2 & 40 & 2 & 40 & 50 \\
\hline $\mathrm{C}$ & 2 & 40 & 0 & 0 & 0 & 0 & 0 & 0 & 10 \\
\hline $\mathrm{D}$ & 0 & 0 & 0 & 0 & 0 & 0 & 0 & 0 & 0 \\
\hline
\end{tabular}

Observation on the social skill of the students during the learning process displayed in Table 3 shows that category variation starts from sufficient, good, to very good. However, all of them are dominated by good and very good categories.

The learning resulted from inquiry based learning is expected to grow students' social skill. The cooperative learning model is used to obtain at least three learning goals; they are to fix the academic learning outcome, individual acceptance and social skill development [21]. The social skill of the students, when it is observed through a questioning parameter, shows category variations of attitudes on each student in one group which generally are positive. Some students have very good social skills, and some others have good social skills although some students only have fair social skills at the beginning meeting.

In group learning, students are given chances to interact with each other and explain each other definition on a concept to their peers. The interaction happening among students in a group leads them to ask each other and explain in return when they try to understand a concept or solve the problem together. The observation result on the social skill of the students are generally in good category and goes along with Lestari [21] research result that children social skill can develop well when the learning process is set to be in the group. It also supports the theory of Vygotsky who explains that social interaction plays the main basic role in children knowledge development. Student social interaction during the learning process has a positive correlation with his or her ability to understand the certain concept as the result of questioning each other or digging information from one another. 
The observation result on the students' social skill also indicates that during the learning process a lot of students were involved in active participation and cooperated with their group members to work on the problem in the workbook. The cooperation activity shows in the form of a discussion among group members through question and answer. The conclusion that questioning skill of the students can be trained in the group discussion is also in line with Prayitno's research result which reported STAD cooperative learning model in which students' discussion among them can facilitate scaffolding process through peer tutorial [22]. In other words, the inquiry based learning model can be implemented to grow students' social skill, as the research points out.

One of the active learning characteristics is that students do not only listen to passive learning material but work on something that is related to the learning [23]. Inquiry based learning trains the students to explore the question, find the answer, and share knowledge with others [24]. This means the inquiry approach puts students as learning subjects. Students get a learning experience which makes them possess certain learning ability in a learning material concept. The learning experience occurs during the learning process. As long as students try to find out that concept, a questioning skill will appear within themselves.

During a certain period, students who learn through inquiry based learning will test their own ideas or other people who work with them, ask each other, communicate ideas, and appreciate other people [16]. These attitudes can be occured through these activities. In conclusion, character attitude and social skill can be facilitated through inquiry based learning.

\section{CONCLUSION}

Inquiry based learning at senior high school can help students to achieve good character and social skills. Character behaviors include cooperation that reaches good category $(55 \%)$ and appreciates friends who reach good category (50\%) and very good $(50 \%)$. The social skills of students which includes indicators of questioning skills have reached the good category $(50 \%)$. Therefore, it is recommended that inquiry based learning can be applied in the classroom by teacher and in the implementation, and it is expected that the teacher is aware of any other possible factors, such as students' condition, subject concept, and time allocation available for the learning process.

\section{ACKNOWLEDGMENT}

We thank SMA Negeri 2 Banjarbaru which has provided the opportunity and collaboration in this study.

\section{REFERENCES}

[1] National Education System Law, Law No. 20 on National Education System of Republic of Indonesia. States Secretary, 2003.

[2] Rules of Education and Culture Minister, Regulation of Minister of Education and Culture Republic of Indonesia No. 23 on Education Assessment Standards. Indonesia: Ministry of Education and Culture, 2016.

[3] G. W. Friedrich, "Methods and Problems of Pre- and Postcommunication Competency Assessment," in 58th Annual Meeting of the Speech Communication Assn.Chicago, December 27-30, 1972, pp. $1-9$.

[4] X. Liu, Using and developing measurement instruments in science education: a Rasch modelling approach. North Carolina: Information Age Publishing Inc., 2010.

[5] I. Eshun, "Domain of educational objectives social studies teachers' questions emphasise in Senior High School in Ghana," J. Educ. Pract., vol. 4, no. 4, pp. 185-196, 2013.

[6] I. Bilgin, "The Effects of Guided Inquiry Instruction Incorporating a Cooperative Learning Approach on University Students Outcome of Acid and Base Concept and Attitude Toward Guided Inquiry Instruction," Sci. Research Essay, vol. 4, no. 10, pp. 1038-1046, 2009.

[7] C. Meyer and T. B. Jones, Promoting active learning: strategies for the college classroom. San Francisco: Jossey-Bass, 1993.

[8] O. Luiminigh, Writing Learning Outcomes: a Guide for Academics. Irlandia: University of Limerick, 2007.

[9] S. A. Kamaruddin, "Character Education and Students Social Behavior," J. Educ. Learn., vol. 6, no. 4, pp. 223-230, 2012.

[10] R. E. Slavin, "What makes cooperative Learning: What makes group work?," Pedagog. Lead. Learn., vol. 1, no. 2, pp. 32-35, 2006.

[11] N. Y. Ermawati and P. Abidin, "Implementation of Inquiry-Based Learning to Reading Comprehension of EFL Students," Int. J. Sci. Res., vol. 6, no. 3, pp. 1067-1071, 2015.

[12] J. Lexmond and R. Richard, Character Building. London: Demos, 2009.

[13] R.-C. Cathrine., M. Karisma, M. Chelsea, C. Antonia, L. Cynthia, and K. Sacha, "Do Inquiring Minds Have Positive Attitudes? The Science Education of Preservice Elementary Teachers," Sci. Educ., vol. 95, no. 5, pp. 819-836, 2015.

[14] Z. Bayram, O. O.O., E. Emine, D. O. Sinem, and S. Senol, "Effect of Inquiry Based Learning Method on Students' Motivation," in 4th International Conference on New Horizons in Education, ProcediaSocial and Behavioural Sciences, 2013, pp. 988-996.

[15] Alberta, Knowledge and employability studio instructional strategies teacher workstation inquiry-based learning. Canada: Alberta Education, 2005.

[16] W. Harlen, "Helping children's development of inquiry skills," Inq. Prim. Sci. Educ., vol. 1, pp. 5-19, 2014.

[17] M. Munusamy, "The Cooperative Learning Strategies: A Study on Student Outcome in Moral Education," in International Conference on Education and Regional Development 2016 (ICERD 2016): CrossCultural Education for Sustainable Regional Development., 2016.

[18] Suwondo and S. Wulandari, "Inquiry-based Active Learning: The Enhancement of Attitude and Understanding of The Concept of Experimental Design in Biostatics Course," Asian Soc. Sci., vol. 9, no. 12, 2013.

[19] D. O. Maxwell, D. T. Lambeth, and J. T. Cox, "Effects of Using InquiryBased Learning on Science Outcome for Fifth-Grade Students," AsiaPacific Forum Sci. Learn. Teach., vol. 16, no. 1, pp. 1-31, 2015.

[20] A. Veloo, P. Selvan, and V. R., "Inquiry-based Instruction, Student's Attitudes and Teachers' Support Towards Science Outcome in Rural Primary Schools," Procedia-Social Behav. Sci. 3rd World Conf. Learn., vol. 93, pp. 65-69, 2013.

[21] N. C. Lestari, "Pengembangan Perangkat RPP Konsep Air dengan Pendekatan Kontekstual (CTL) dan Pengaruhnya Terhadap Hasil Belajar dan Kemampuan Berpikir Kritis Siswa SD," Thesis of Biology Education Graduate Program of Lambung Mangkurat University, 2012.

[22] B. A. Prayitno, "Pengembangan perangkat RPP IPA Biologi SMP Berbasis Inkuiri Terbimbing Dipadu Kooperatif STAD Serta Pengaruhnya terhadap Kemampuan Berpikir Tingkat Tinggi, Metakognisi, dan Keterampilan Proses Sains pada Siswa Berkemampuan Akademik Atas dan Bawah," Dissertation, Study Program of Biology, Graduate Program Universitas Negeri Malang, 2011.

[23] A. Rooijakkers, Mengajar dengan Sukses. Jakarta: Grasindo, 1991.

[24] K. Murdoch, Take a Moment: 40 Frameworks for Reflective Thinking. Melbourne: Seastar Education, 2005. 